\title{
Peran Komisi Pemilihan Umum Dan Pengawas Pemilu Untuk Pemilu Yang Demokratis
}

\author{
Suparman Marzuki \\ Fakultas Hukum UII Jl. Taman Siswa No 158 Yogyakarta \\ e-mail:suparman@fh.uii.ac.id
}

\begin{abstract}
To build a strong and reliable democratic institution, is a time consuming process which also requires a long patience. Accordingly, three pillars of General Election Commission (KPU), namely, structural independency, functional independency and personal independency, shall be consistently kept up and maintained.
\end{abstract}

Keywords: General Election Commission, General Election Supervisory Board, Democratic

\section{Pendahuluan}

UUD 1945 Pasal 22-e berbunyi, "Pemilihan Umum dilaksanakan oleh suatu komisi pemilihan umum". Kata komisi dengan huruf (k) kecil dimaknai bahwa pelaksana suatu pemilihan umum bisa saja bukan KPU seperti yang di kenal sekarang, bisa kelembagaan dalam bentuk lain. Tetapi UU No. 12 Tahun 2003, yang telah diubah dengan UU No. 10 Tahun 2008; UU No. 23 Tahun 2003; dan UU No. 22 Tahun 2007, telah menyebutkan dengan jelas bahwa tafsir atas "suatu komisi pemilihan umum", yaitu Komisi Pemilihan Umum yang sekarang ada.

Kehadiran KPU tahun 2001, Panwaslu tahun 2003 dan sekarang Bawaslu memunculkan harapan, sekaligus pertanyaan tentang kemampuan KPU dan Bawaslu ${ }^{1}$ melaksanakan proses Pemilu yang bersih, jujur, adil dan transparan. Oleh sebagian (besar) pemerhati dan masyarakat, lembaga ini diapresiasi begitu tinggi dan diyakini mampu

${ }^{1}$ UU No. 22 tahun 2007 mengatur bahwa Badan Pengawas Pemilu (Bawaslu) berada di tingkat nasional bersifat permanen, sementara Panwaslu berada di tingkat Provinsi, Kabupaten/Kota, Kecamatan dan Lapangan yang bersifat ad hoc. 
menyelenggarakan Pemilu yang bersih dan demokratis. Harapan dan keyakinan demikian itu sesuatu yang wajar karena kekhawatiran masyarakat terhadap kecurangan-kecurangan Pemilu yang pernah dipraktikkan di era Orde Baru yang lalu terekam kuat dalam memori masyarakat. ${ }^{2}$

Pengalaman traumatik itu pada satu sisi tentu positif, karena memunculkan reaksi sosial produktif (dukungan) kepada kehadiran KPU dan Panwaslu, meskipun potensi kontraproduktifnya sangat tinggi juga apabila harapan yang diberikan tidak mampu diwujudkan. Kecaman niscaya bermunculan; tidak perduli apakah akibat dari ketidakmampuan itu melulu karena internal KPU dan Panwaslu atau karena variabel-variabel lain di luar lembaga tersebut; tudingan pasti dialamatkan ke lembaga bersangkutan.

\section{Pemilu di era Transisi}

Pemilihan umum adalah salah satu pilar utama demokrasi. Sentralitas dari posisi pemilihan umum dalam membedakan sistem politik yang demokratis atau bukan, tampak jelas dari beberapa definisi demokrasi yang diajukan oleh para sarjana. Salah satu konsepsi modern awal mengenai demokrasi diajukan oleh Joseph Schumpeter (mazhab Schumpeterian) yang menempatkan penyelenggaraan pemilihan umum yang bebas dan berkala sebagai kriteria utama bagi suatu sistem politik untuk dapat disebut demokrasi. ${ }^{3}$

Dalam khazanah demokrasi kontemporer posisi pemilihan umum memperoleh penguatan. Kajian akademis mengenai demokrasi mengenal dua kategorisasi pemaknaan besar, yaitu konsepsi minimalis dan maksimalis. ${ }^{4}$ Demokrasi minimalis ${ }^{5}$ atau dalam wacana di Indonesia lebih

${ }^{2}$ Kita tahu bahwa Pemilu di era itu diselenggarakan dengan proses dan prosedur yang tidak bisa diprediksi (unpredictable), tetapi hasil Pemilu sudah bisa diperkirakan (predictable); siapa yang akan keluar jadi pemenang dan siapa yang akan menjadi Presiden sudah bisa diketahui.

${ }^{3}$ Lihat Joseph Schumpeter (1947) Capitalism, Socialism, and Democracy, New York: Harper, hal. 122. Untuk argumentasi serupa dalam khazanah keilmuan yang lebih kontemporer, lihat Samuel P. Huntington (1991) The Third Wave: Democratization in the Late Twentieth Century,Norman: Oklahoma University Press, hlm. 636.

${ }^{4}$ Banyak sarjana menulis tentang kategorisasi seperti ini. Lihat misalnya Larry Diamond (1999) Developing Democracy: Toward Consolidation, Baltimore: The Johns Hopkins University Press

${ }^{5}$ Menurut teori demokrasi minimalis, pemilu merupakan sebuah arena yang mewadahi kompetisi antar aktor-aktor politik rakyat meraih kekuasaan; partisipasi politik untuk menentukan pilihan; serta liberalisasi hak-hak sipil dan politik warga 
dikenal dengan demokrasi prosedural dikenakan kepada sistem politik yang melaksanakan perubahan kepemimpinan secara reguler melalui suatu mekanisme pemilihan yang berlangsung bebas, terbuka, dan melibatkan massa pemilih yang universal (tanpa pembedaan ras, agama, suku, dan gender). Bagi konsepsi maksimalis pelaksanaan pemilihan umum saja tidaklah cukup bagi suatu sistem politik untuk mendapatkan gelar demokrasi, karena konsepsi ini (yang di Indonesia lebih dikenal dengan peristilahan demokrasi substantif) mensyaratkan penghormatan terhadap hak-hak sipil yang lebih luas, dan penghargaan terhadap kaidah-kaidah pluralisme yang mendasar. ${ }^{6}$

Bila ditilik lebih jauh, kedua konsepsi tersebut menjadikan pemilihan umum sebagai prasyarat bagi demokrasi. Karenanya, sebuah rezim yang menjamin pluralitas dan hak-hak sipil tetapi tidak melakukan pergantian kekuasaan secara reguler melalui pemilihan umum tidak dapat mengklaim dirinya sebagai negara demokrasi. Walaupun akhir-akhir ini terdapat serangkaian kritik terhadap pendapat yang mengedepankan prosedur demokrasi ini, posisi pemilihan umum tetaplah dipandang sentral dalam wacana demokrasi.

Wacana konsolidasi kemudian menjadi isu baru yang menarik dikaji. Bila digambarkan sebagai sebuah spektrum, konsolidasi akan mengentalkan warna demokrasi dari kategori minimalis yang berwarna muda menuju ke arah maksimalis yang berwarna lebih pekat. Kepentingan konsolidasi biasanya kerap diterapkan pada negara-negara yang baru saja meninggalkan otoritarianisme menuju ke demokrasi. Tatkala negaranegara ini menempuh jalan panjang ke arah demokrasi, langkah pertama yang lazim ditempuh adalah langkah-langkah minimalis, seperti menyelenggarakan pemilihan umum yang terbuka, bebas dan adil, dan pemberian hak-hak politik dasar kepada seluruh warganegara tanpa perkecualian yang didasarkan pada ras, agama, dan gender.

Untuk menuju ke arah demokrasi maksimalis, konsolidasi demokrasilah jalannya. Penerapan konsolidasi hanya pada negara-negara demokrasi baru sebenarnya agak salah kaprah karena demokrasi

Negara. Kajian kritis dan menarik atas pandangan Scumpater dapat dibaca dalam tulisan Adam Prezeworski, dalam Ian Shapiro \& Casioano Hacker-Cordon (ed), "Democracy"s Value", Cambridge University Press, 1999, hlm. 23-50.

${ }^{6}$ Ada banyak kritik ditujukan terhadap demokrasi prosedural, antara lain lihat Fareed Zakaria; The Future of Freedom: Illiberal Democracy at Home and Abroad, (2003), New York: W.W. Norton. 
sesungguhnya adalah proses yang tidak pernah berhenti. Suatu negara yang demokrasinya dipandang telah terkonsolidasi dapat saja mengalami arus balik yang membahayakan posisi demokrasi itu sendiri.

Dalam satu sistem terbuka sangat lazim bila terdapat pengharapan yang meningkat secara terus menerus, dan bukan merupakan keanehan bila sistem pemerintahan transisi, bahkan dalam berbagai kasus di dunia, tidak mampu berlari lebih cepat untuk memenuhi pengharapan tersebut sehingga pemerintahan era Reformasi banyak dipandang gagal dalam memenuhi tujuan-tujuan awalnya.

Pandangan tersebut bukan hanya ditujukan pada rendahnya pencapaian pemerintah dalam memenuhi hajat hidup orang banyak setelah didera oleh krisis ekonomi pada tahun 1997/1998, namun juga kegagalan negara menghargai pluralisme bagi seluruh warganya. ${ }^{7}$ Sedangkan sangat kelihatan adalah kelemahan pemerintah dalam menerapkan prinsip "hukum sebagai panglima" pada berbagai aspek, meski terdapat institusi-institusi hukum yang lahir di era reformasi yang diharapkan mengawal tegaknya konstitusi, seperti Mahkamah Konstitusi (MK), Komisi Yudisial (KY), dan perubahan pelbagai undang-undang bidang penegakan hukum dan seterusnya. Tetapi sangat disayangkan semua itu belum menunjukkan gelagat kuat bahwa kekuasaan politik telah menjadi subordinat dari kekuasaan hukum. ${ }^{8}$

Situasi demikian potensial membuat proses demokrasi akan layu sebelum berkembang, atau dalam istilah Georg Sorensen ${ }^{9}$ sebagai demokrasi beku (frozen democracies) atau demokrasi lemah, demokrasi tidak solid atau demokrasi yang rentan (fragile democracy). ${ }^{10}$ Orde yang tua sudah ambruk, tetapi yang baru tidak kunjung lahir. Jadi ada suasana kekosongan yang menakutkan. Inilah warisan yang paling mengerikan dari suatu masyarakat sipil yang disorganiszed yang dihasilkan oleh Orde Baru sepanjang sejarah kekuasaannya.

${ }^{7}$ Kesukaran pemerintahan pasca Soeharto menghapus soal ini tidak lepas dari kebijakan politik Orde Baru yang berorientasi pada Negara kuat demi menopang proses pembangunan ekonomi yang mengikuti jalan kapitalisme terpimpin (state-led capitalist development). Analisis menarik dapat dibaca dalam AS. Hikam, Politik Kewarganegaraan Landasan Redemokratisasi di Indonesia, Erlangga, 1999, hlm. 2 dst.

${ }^{8}$ Analisis kritis Moh. Mahfud MD tentang kegalauan terhadap belum bekerjanya hukum sebagai panglima dalam sistem politik di era reformasi dapat dibaca dalam bukunya, "Membangun Politik Hukum Menegakkan Konstitusi, LP3ES, 2006.

${ }^{9}$ Georg Sorensen, Demokrasi dan Demokraratisasi Proses dan prospek dalam Sebuah Dunia yang Sedang Berubah, (terj), Pustaka Pelajar \& CCSS, 2003, hlm. xiii

${ }^{10}$ Lihat "Menuju Pemilihan Umum Transformatif, IRE, Annual Report 2003/2004, hlm. 16 
Kembali ke masalah Pemilu yang digelar di era transisi ini, perdebatan antara demokrasi prosedural dan substantif memang sangat terasa menjelang Pemilu 2004 yang lalu. Sebagian pengamat menginginkan agar di era transisi ini perwujudan warna demokrasi substansial harus lebih kental, tetapi sebagian lain menyatakan bahwa demokrasi prosedural di era transisi sesuatu yang harus dilalui; sebagaimana dialami banyak negara yang baru lepas dari kekuasaan otoritarian. Lebih dari itu, demokrasi prosedural-lah yang bisa menjadi ukuran, sekaligus dapat dilihat apakah transisi di suatu negara sedang berlangsung atau tidak. ${ }^{11}$

Demokrasi prosedural menurut Gregorius Sahdan merupakan salah satu instrumen transisi rezim otoritarian gelombang pertama, kedua sampai dengan yang ketiga; memberikan peranan yang besar terhadap kemerdekaan individu, keterlibatan publik dan jaminan hak warga negara dalam pemerintahan; merupakan jembatan yang memberikan arah bagi peralihan rezim non-demokratik; dan dapat dengan mudah melihat; apakah ada fakta transisi; apakah ada Pemilu dalam transisi; apakah Pemilu dilaksanakan dengan Jurdil; apakah ada pembentukan lembaga-lembaga demokratis; dan apakah lembaga-lembaga demokratis itu berfungsi. ${ }^{12}$

Keseluruhan komponen penilaian tersebut dapat menjadi barometer untuk membedakan antara perubahan ke demokrasi atau kembali ke otoritarianisme; atau dengan kata lain demokrasi prosedural-lah yang bisa memperlihatkan arah atau kecenderungan politik dan hukum yang sedang dituju; apakah proses demokrasi atau transisi demokrasi kuat ke arah terbangunnya demokarasi sesungguhnya atau justru membalik jarum sejarah; kembali ke kekuasaan non demokratis.

Di luar perdebatan tersebut, situasi tidak adanya partai yang kokoh dengan agenda pembaruan yang jelas.Tidak adanya partai besar dengan agenda pembaruan rule of law menjadi fakta lain yang mewarnai situasi politik Indonesia menjelang Pemilu 2004 yang lalu. ${ }^{13}$ Karena itulah Vedi

${ }^{11}$ Gregorius Sahdan, Jalan Transisi demokrasi Pasca Soeharto, Pondok edukasi, 2004, hlm. 14-15

${ }^{12}$ Ibid

${ }^{13}$ Pandangan tersebut muncul sebagai reaksi atas proses dan hasil Pemilu 1999 yang menghadirkan dua sisi paradoksal. Sisi pertama, masyarakat berharap pemilu 1999 sebagai kesempatan baru untuk mengakhiri kemelut krisis ekonomi-politi, harapan lahirnya pemimpin-pemimpin baru yang betul-betul mampu menciptakan keamanan, kesejahteraan dan seterusnya. Sisi kedua, gagasan ideal demokrasi tentang Pemilu justru mengalami distorsi dan anomali. Salah satu penyebab anomali adalah ketiadaan visi dan misi bersama untuk apa Pemilu digelar. 
R Hadits ${ }^{14}$ secara tegas pernah memperkirakan bahwa Pemilu 2004 tidak akan besar maknanya bagi proses demokrasi di Indonesia. Bahkan menurutnya "transisi" di Indonesia telah berakhir, dan hasilnya bukanlah "demokrasi liberal", tetapi suatu sistem yang ciri, pola, logika dan dinamika mendasarnya dibentuk dan dijalankan oleh politik uang dan kekerasan. ${ }^{15}$

Itu sebabnya sejumlah ilmuwan politik menawarkan gagasan "pemilu transformatif" pada jiwa Pemilu 2004 yang lalu, yaitu Pemilu yang tidak sekedar proses elektoral yang sehat dan demokratis, tetapi sebagai kesempatan untuk memulai perubahan ke depan, serta Pemilu yang menjadikan rakyat pemilih sebagai pemilih yang bebas dan rasionalotonom. ${ }^{16}$ Dalam kondisi seperti itulah Pemilu 2004 di gelar; yaitu Pemilu yang mengusung harapan terwujudnya demokrasi prosedural yang berlangsung transparan, fair, adil dan damai sebagai jalan konsolidasi demokrasi ${ }^{17}$ bagi kekuatan-kekuatan sipil dengan kecemasan menjadi momen konsolidasi kekuatan-kekuatan lama, yaitu Golkar-Tentara dan Birokrasi bagi kembalinya format politik lama, atau setidak-tidaknya modifikasi dari otoritarianisme Orde Baru. ${ }^{18}$

\section{Komisi Pemilihan Umum}

KPU yang dikonsepsikan secara hukum dan politik berbeda dengan KPU sebelumnya (1999) untuk menyelenggarakan Pemilu dengan sistem yang berbeda dibanding Pemilu di era Orde Baru dan Pemilu 1999, jelas mengemban harapan besar dari kekuatan-kekuatan sipil (pro demokrasi) untuk menjadi penyelenggara yang independen, sehingga mampu menjaga proses yang fair, adil dan transparan dengan hasil yang dipercaya rakyat. Hanya dengan kewenangan dan kelembagaan yang independen itulah Pemilu dapat menciptakan lembaga-lembaga perwakilan rakyat

${ }^{14}$ Vedi R Hadits, dalam "Gerakan Demokrasi di Indonesia Pasca Soeharto", AE. Priyono, dkk (ed), Demos, 2003, hlm. 61.

${ }^{15}$ Ibid, hlm. 62

${ }^{16}$ Baca Annual Report 2003/2004, Menuju Pemilihan Umum Transformatif, IRE Yogyakarta, IRE Press, 2004

${ }^{17}$ Konsolidasi demokrasi menurut Gregorius Sahdan berada pada fase III dari Pemilu setelah sebelumnya dilakukan Fase I Pemilu mengakhiri pemerintahan nondemokratik lali pemilu fase ke II, melantik pemerintahan demokratik. Secara lengkap Baca Analisis CSIS, Tahun XXII/2003 No. 2. hlm. 203

${ }_{18}$ Analisis menarik tentang proses demokrasi yang sedang berlangsung di Indonesia baca Ignas Kleden dan Leo Agustiono dalam Analisis CSIS, Tahun XXII/ 2003 No. 2. hlm. 160-191 
yang lebih berkualitas di satu sisi, dan menjaga kesinambungan proses demokrasi yang sedang dibangun di sisi lain. ${ }^{19}$

KPU adalah lembaga penyelenggara pemilu yang dijamin dan dilindungi UUD 1945, dan karena itu dikategorikan sebagai lembaga negara yang memiliki apa yang disebut dengan constitutional importance..$^{20}$ Sebagai lembaga yang penting, KPU ditegaskan bersifat nasional, tetap, dan mandiri (independen) ${ }^{21}$ yang derajat kelembagaannya sama dengan lembaga-lembaga negara yang lain yang dibentuk dengan undang-undang.

Independensi ${ }^{22}$ telah menjadi asas universal bagi lembaga-lembaga yang dibentuk untuk melaksanakan Pemilu, mengawasi pemerintah, atau lembaga investigasi atas kesalahan atau kejahatan-kejahatan yang dilakukan pemerintah (Government) atau agen-agen pemerintah (state agent). Dean Gottehrer, konsultan Ombudsman internasional menyatakan bahwa, independensi adalah asas paling esensial karena menentukan kesinambungan, fungsi, pemanfaatannya, kedudukan dan fasilitas lembaga bersangkutan. ${ }^{23}$

Independensi tidak sekadar bermakna "merdeka, bebas, imparsial, atau tidak memihak" dengan individu, kelompok atau organisasi kepentingan apapun, atau tidak tergantung atau dipengaruhi. Independensi bermakna pula sebagai kekuatan/power, paradigma, etika, dan spirit untuk menjamin suatu proses dan hasil dari Pemilu merefleksikan kepentingan rakyat, bangsa dan negara, sekarang dan yang akan datang.

Independensi yang harus dipelihara dan dipertahankan oleh lembaga yang diberi independensi meliputi tiga hal, yaitu: independensi institusional,

${ }^{19}$ Sudarsono, Mahkamah Konstitusi Sebagai Pengawal demokrasi, Penyelesaian Sengketa Hasil Pemilu 2004 Oleh Mahkamah Konstitusi, 2005, hlm. 122

${ }^{20}$ Jimly Asshiddiqie, Perkembangan dan Konslidasi Lembaga Negara Pasca Reformasi, Sekretariat Jenderal dan Kepaniteraan Mahkamah Konstitusi RI, 2006, hlm. 235

${ }^{21}$ Pasal 22E ayat (5) UUD 1945.

${ }^{22}$ Dalam bahasa Inggris menurut database kamus Wordnet yang saya baca melalui aplikasi [url=http:/ / stardict.sf.net]stardict[/url], independent memiliki arti: (1) free from external control and constraint; "an independent mind"; " a series of independent judgments"; "fiercely independent individualism"; " an independent republic" [ant: (dependent); (2) not dependent on or conditioned by or relative to anything else; (3) of political bodies; "an autonomous judiciary"; "a sovereign state" [syn: \{autonomous\}, \{self-governing\}, \{sovereign\}]; (4) not contingent; (5) (grammar) of a clause; able to stand alone syntactically as a complete sentence; "the main (or independent) clause in a complex sentence has at least a subject and a verb" [syn: \{main(a)\}] [ant: \{dependent\}, dan (5) not controlled by a party or interest group.

${ }^{23}$ Dean Gotteher, "Ombudsman Legislative Resource Document, Occassional Paper, International Ombudsman Institute, 1998, hlm. 65 
independensi fungsional, dan independensi personal. Independensi institusional atau struktural adalah bahwa KPU bukan bagian dari institusi negara yang ada, tidak menjadi sub-ordinat atau tergantung pada lembaga negara atau lembaga apapun. Independensi fungsional dimaksudkan bahwa KPU tidak boleh dicampuri atau diperintah dan di tekan oleh pihak manapun dalam melaksanakan Pemilu, dan independensi fungsional adalah bahwa seseorang yang menjadi anggota KPU adalah personal yang imparsial, jujur, memiliki kapasita dan kapabilitas. Hanya dengan begitu, sebuah Komisi (termasuk Ombudsman) kata Gottehrer dan Michael Hostina dapat bersikap tidak memihak (impartial), bebas (independent), adil (fair), dan terpercaya (credible). ${ }^{24}$

Sifat independen tersebut relatif telah dijabarkan di dalam beberapa pasal dalam UU No. 22 Tahun 2007 yang merupakan kerangka legal bagi tiga aspek independeni dimaksud. Independensi struktural yang ditegaskan dalam UUD 1945 di atas, secara relatif telah dijamin pula oleh UU No. 22 tahun 2007 ke dalam beberapa Pasal. Pertama, dalam Pasal 15 ayat (3) yang menyatakan bahwa KPU dalam melaksanakan tugasnya menyampaikan laporan dalam tahap penyelenggaraan Pemilu kepada Presiden dan DPR. Laporan yang dimaksud Pasal ini bukan dalam pengertian pertanggungjawaban, tetapi lebih merupakan pemberian informasi kepada lembaga negara terkait. Kedua, dalam Pasal 16 ayat (3) yang menyatakan bahwa Ketua dan Wakli ketua dipilih dari dan oleh anggota. Jadi bukan ditentukan atau ditunjuk oleh lembaga lain.

Independensi fungsional dapat dibaca dalam Pasal 25 yang memberi kewenangan kelembagaan menetapkan rencana, organisasi dan tata kerja Pemilu, mengendalikan Pemilu, menetapkan peserta Pemilu, menetapkan daerah pemilihan, menetapkan waktu, menetapan hasil Pemilu, dan melaksanakan kewenangan lain yang diatur undang-undang. Sementara independensi personal tersurat jelas dalam syarat-syarat menjadi anggota KPU yang diatur dalam Pasal 18, antara lain misalnya: mempunyai integritas pribadi yang kuat, jujur, dan adil. Mempunyai komitmen dan dedikasi terhadap suksesnya Pemilu, tegaknya demokrasi dan keadilan; tidak menjadi anggota atau pengurus parta politik; dan tidak sedang menduduki jabatan politik, jabatan struktural dan jabatan fungsional dalam jabatan negeri.

${ }^{24}$ Dean Gottehrer and Michael Hostina, "Essential Characteristics of a Classical Ombudsman" (USOA), http:/ / www.usombudsman.org). 
Meskipun independensi merupakan standar universal bagi lembaga penyelenggara Pemilu dimana pun, tetapi toh tetap dipertanyakan oleh terutama kalangan praktisi politik. Prinsip independensi KPU mereka nilai sebagai keputusan gegabah. Sebab orang independen dan non-partisan seringkali justru tidak mengetahui seluk beluk dunia politik, apalagi Pemilu. ${ }^{25}$ Setelah Pemilu 2004 yang lalu, gugatan terhadap independsi KPU kembali dimunculkan oleh pemerintah dan Parpol tertentu dengan memunculkan kasus-kasus di KPU serta kendala tehnis Pemilu sebagai alasan untuk merubah sistem KPU. ${ }^{26}$ Keinginan ini dikritik keras oleh Denny Indrayana sebagai sikap berlebihan. Denny menyatakan, “janganlah kritik berlebihan kepada KPU menyebabkan kita merombak kemandirian KPU dan menghilangkan sistem pengorganisasian pemilu yang mulai dirintis KPU kali ini. ${ }^{27}$

Sikap berlebihan sebagian kalangan itu direspon oleh romo Magnis sebagai sikap kurang bermoral, dan menyatakan; "bila dalam pemilu 2004 lalu, di negara seruwet Indonesia, terjadi hanya lima persen ketidakberesan, pemalsuan, manipulasi, pemilu itu harus diakui sebagai sukses. Itu bukan hanya tuntutan realisme. Itu tuntutan kejujuran dan kewajaran moral. ${ }^{28}$

Karena itu, pandangan kalangan Partai Politik yang menilai Pemilu 2004 tidak lebih baik dari Pemilu 1999 jelas mengada-ada dan a-historis. Mereka lupa bahwa anggota KPU 1999 yang berasal dari Parpol justru mengalami anarki; selain terus menerus terlibat "perkelahian internal" karena mempertahankan kepentingan Parpolnya masing-masing; hasil Pemilu-pun pada akhirnya terpaksa disyahikan oleh Presiden, bukan oleh KPU sebagaimana mestinya menurut undang-undang. Inilah yang memperkuat keyakinan Adnan Buyung Nasution, salah seorang anggota KPU Pemilu 1999 dari unsur independen akan pentingnya anggota KPU bersifat independen.

Buyung menegaskan; "Saya setuju KPU yang independen, karena hasilnya nanti akan lebih baik, tidak akan dipengaruhi oleh kepentingan partai, dan pekerjaan juga akan bisa lancar, tidak akan ada yang

${ }^{25}$ Lihat Koirudin, Profil Pemlu 2004 Evaluasi Pelaksanaan, Hasil dan Perubahan Peta Politik Nasional Pasca Pemilu Legislatif 2004, Pustaka Pelajar, 2004, hlm.34

${ }^{26}$ Pemerintah dan sebagian anggota DPR bersikeras agar asas independensi dihilangkan karena dengan cara demikian keinginan pemerintah (terutama) untuk memasukkan PNS sebagai anggota KPU terbuka.

${ }^{27}$ Lihat Denny Indrayana dalam "Siapa Mau Jadi Presiden", Kompas, 2004, hlm. 254

${ }^{28}$ lihat Franz Magnis Suseno, dalam "siapa Mau Jadi Presiden", Kompas, 2004, hlm. 248 . 
menyerobot, ${ }^{29}$ dan hasilnya akan melahirkan sebuah lembaga legislatif yang demokratis pula. ${ }^{30}$ Lebih-lebih Partai Politik kita masih jauh dari kedewasaan politik untuk menerima proses dan hasil apapun dari Pemilu yang jujur, fair, dan transparan. Parpol-parpol kita kata Franz Magnis Suseno, masih terbelenggu mental bad losers (tidak mampu menerima kekalahan) padahal lanjut Romo Magnis, salah satu keutamaan demokratis paling dasar adalah kesediaan menerima kekalahan itu dengan baik, atau dalam istilah John Raw, tidak fair dengan perbedaan pendapat, ${ }^{31}$ tetapi parpol-parpol itu tidak menggunakan kesempatan menunjukkan diri sebagai noble losers kepada masyarakat. ${ }^{32}$

Karena itulah, Buyung menegaskan bahwa, hanya Pemilu yang bebas dan bersih yang memungkinkan mengadakan perubahan-perubahan politik, baik perubahan susunan kekuasaan politik maupun penguasa politik. ${ }^{33}$ Pemilu yang dilakukan oleh Orde Baru kata Buyung merupakan proyek pembodohan karena rakyat diberikan hak pilih, tapi pilihannya sudah ditentukan. ${ }^{34}$

Dalam konteks ilmu politik kontemporer, KPU yang independen diharapkan tampil sebagai aturan dan kendala yang akan mengurangi ketidakpastian dengan cara menetapkan struktur yang stabil dan dapat diperkirakan bagi interaksi manusia, baik sebagai individu maupun sebagai kelompok. Dalam istilah Ramlan Surbakti, ${ }^{35}$ KPU adalah institusi demokrasi yang harus menjaga dan memastikan prosedur yang terpola dan pasti (predictable procedures) dalam melaksanakan Pemilu sehingga hasilnya tidak dapat diketahui (unpredictable results).

Arti penting prinsip Independensi itu lanjut Ramlan ${ }^{36}$ didasarkan kepada empat hal. Pertama, pemilihan umum merupakan prosedur dan

${ }^{29}$ Baca Adnan Buyung Nasution, Pergulatan Tanpa Henti Pahit Getir Merintis demokrasi, Aksara Karuna, 2004, hlm. 59

${ }^{30}$ Lihat Afan Gaffar, Politik Indonesia Transisi Menuju Demokrasi, Pustaka Pelajar, 2005, hlm. 269

${ }^{31}$ Andre Ata Ujan, Keadilan dan Demokrasi Telaah Filsafat Politik John Rawls, Kanisius, 2001, hlm. 103 hlm. 249

${ }^{32}$ Lihat Franz Magnis Suseno, dalam “Siapa Mau Jadi Presiden", Kompas, 2004,

${ }^{33}$ Baca Adnan Buyung Nasution dalam "Mendidik Manusia Merdeka" 65 Tahun Y.B. Mangunwijaya, interfidei, 1995, hlm.390

${ }^{34}$ Ibid, hlm. 391

${ }^{35}$ Ramlan Surbakti, "Demokrasi Menurut Pendekatan Kelembagaan Baru”, Jurnal Ilmu Pemerintahan, edisi 19 Tahun 2003, hlm.4-5

${ }^{36} \mathrm{Ibid}$ 
mekanisme pendelegasian sebagian kedaulatan rakyat kepada penyelenggara negara, baik yang akan duduk dalam lembaga legislatif maupun dalam lembaga eksekutif di pusat dan daerah, untuk bertindak atas nama rakyat dan mempertanggungjawabkannya kepada rakyat. Kedua, pemilihan umum merupakan prosedur dan mekanisme pemindahan perbedaan aspirasi dan pertentangan kepentingan dari masyarakat kedalam lembaga penyelenggara negara, baik di pusat maupun di daerah, untuk kemudian dibicarakan dan diputuskan secara beradab. Ketiga, pemilihan umum merupakan prosedur dan mekanisme perubahan politik secara teratur/tertib dan periodik baik perubahan berupa sirkulasi elit politik maupun perubahan arah dan pola kebijakan publik.

Dalam kontek peran KPU menyelenggarakan Pemilu dengan prinisp proses yang terprediksi dan hasil yang tidak dapat diketahui itu, merupakan syarat yang mau tidak mau harus dipenuhi karena menurut Huntington ${ }^{37}$ Pemilu di era transisi merupakan: pertama, "tanda" berakhirnya rezim non demokratik (the inaguration on democratic rezim), sekaligus sebagai "pelembagaan demokrasi" dan pembangunan kembali kohesi sosial yang telah retak yang disebabkan oleh terjadinya tarik menarik dukungan dan penolakan antara berbagai kelompok sosial dalam masyarakat. Kedua, bermakna sebagai pelantikan pemerintahan baru atau rezim demokratik (the inaguration of the democratic rezim) yang menggantikan pemerintahan otoriter yang telah tumbang. Ketiga, pemilu di era transisi merupakan perwujudan dari konsolidasi sistem demokrasi (the inaguration of the democartic system) yaitu suatu usaha untuk menjaga secara ketat kembalinya rezim status quo untuk menduduki kursi kekuasaan.

Karena itu, mandat KPU untuk menyelenggarakan Pemilu di era transisi agar lebih baik dibanding Pemilu 1999 memang sangat berat. Tidak aneh jika kontroversi tentang tingkat kepercayaan banyak kalangan terhadap KPU dari (terutama) para Politisi (DPR) sangat terasa; sampaisampai pengesahan UU No. 22 tahun 2007 yang mengatur keorganisasian dan kewenangan KPU sangat terlambat. ${ }^{38}$ Point yang sangat alot diperdebatkan ${ }^{39}$ adalah mengenai "prinsip independensi KPU" dan

\footnotetext{
${ }^{37}$ Huntington, The Third Wave: Democratitation in The Late Twentieth Century, University of Oklahoma Press, 1991, hlm. 208-210

${ }^{38}$ UU No. 23 tahun 2003 disyahkan bulan Maret 2003, satu tahun menjelang disekenggarakannya Pemilu Legislatif dan DPD

${ }^{39}$ Bivitri Susanti, Menata Ulang Kedudukan Wakil Rakyat, Makalah, hlm. 4
} 
"Pengawas Pemilu". Perdebatan tentang Pengawas Pemilu menurut Ferry Mursidan Baldan, ${ }^{40}$ terfokus pada apakah pengawas pemilu ada di luar KPU, menjadi bagian dari tugas dan kelembagaan KPU atau dibentuk oleh KPU sebagai lembaga mandiri.

Dalam konteks itu lalu apa urgensinya Pengawas Pemilu? Apakah garansi konstitusional yang dipunyai oleh KPU sebagai lembaga mandiri (independen) yang dijamin oleh UUD 1945 dan UU Pemilu tidak bisa dipercaya? Sehingga perlu dibentuk lembaga pengawas Pemilu di luar lembaga KPU?

\section{KPU dan Panwaslu}

Seorang konsultan International Foundation for Election Systems (IFES) sangat heran dengan adanya Panwaslu, sejauh yang ia ketahui, belum pernah ada di muka bumi ini suatu badan pengawas pemilu yang dipisahkan dari penyelenggara pemilihan umum (pemilu), kecuali di Indonesia. ${ }^{41}$ Dalam Pemilu 1999 dan pemilu sebelumnya, pengawasan pemilu itu dilakukan oleh sebuah Panitia Pengawas (Panwas) yang terpisah dari penyelenggara pemilu, yaitu Komisi Pemilihan Umum (KPU). Banyak kritik dilontarkan terhadap kinerja Panwas, termasuk oleh para mantan anggota Panwas sendiri, bahwa kerja Panwas itu tidak efektif dan tidak efisien. ${ }^{42}$

Dalam UU No. 23 Tahun 2003 fungsi pengawasan pemilu itu menjadi bagian dari tugas dan kewenangan pemilu sebagaimana disebutkan dalam pasal 17 ayat (11) dan pasal 120-130. Penyatuan fungsi penyelenggaraan dan pengawasan pemilu itu memang menimbulkan sejumlah pertanyaan. Jika KPU yang melaksanakan pengawasan tersebut, bagaimana dengan prinsip checks and balances? Apakah KPU bisa menjadi lembaga yang mengawasi dirinya sendiri? Apa tidak ada potensi konflik kepentingan dengan penyatuan fungsi penyelenggaraan dan pengawasan pemilu? Apakah obyektivitas KPU melaksanakan pengawasan bisa dijamin?

Oleh sebagian pihak, penyatuan fungsi penyelenggaraan dan pengawasan pemilu oleh KPU ini dinilai berbahaya dan sulit dilakukan. Untuk menyelenggarakan pemilu saja bukan main susahnya, apalagi

\footnotetext{
${ }^{40}$ Pernyataan saat dengar pendapat tentang RUU Penyelenggaraan Pemilu pada 23 September 2005 di DPR RI

${ }^{41}$ Baca Seri Makalah IFES, Bagian 4, Mei 2003, hlm. 12

${ }^{42}$ Pemisahan fungsi pengawasan itu diatur dalam Undang-Undang (UU) Nomor 3 Tahun 1999 tentang Pemilu.
} 
ditambah beban mengawasi pelaksanaan pemilu. Sementara pihak yang menganggap KPU sebaiknya juga mengawasi pelaksanaan pemilu berargumen bahwa fungsi pengalaman empirik pengawasan pada Pemilu 1999 dan pemilu sebelumnya terbukti gagal. Alasan lainnya, KPU mendapatkan kewenangannya dari Undang-Undang Dasar (UUD) 1945, sehingga independensinya terjamin. Oleh karena itu, jangan fungsi pengawasan itu diturunkan derajatnya dengan hanya diatur dalam undang-undang. Dalam konteks checks and balances, penyatuan fungsi pengawasan itu menjadi pengawasan internal KPU. Belum lagi persoalan dana jika lembaga pengawas itu berada di luar KPU, karena hal itu berarti pembangunan infrastruktur baru.

Dalam praktik Pemilu 2004 yang lalu, hubungan kelembagaan dan fungsional KPU dan Panwaslu yang dibentuk KPU ternyata tidak bisa berjalan sebagaimana mestinya. Keduanya sejak awal sudah terjadi pertikaian-pertikaian dari tingkat Nasional-Propinsi-Kabupaten/Kota hingga tingkat kecamatan. Pokok persoalannya terletak pada tiga hal. Pertama, luas lingkup dan makanisme pengawasan. Kedua, ketegangan antara KPU Propinsi, KPU Kabupaten/Kota dan PPK dengan Panwaslu yang sederajat. Ketiga, mekanisme legal penyelesaian masalah yang mengkaitkan peran kedua lembaga tidak jelas/kabur.

Secara yuridis, Panwaslu pusat dibentuk dan bertanggungjawab kepada KPU, sementara Panwaslu Propinsi, Kabupaten/Kota dan Kecamatan dibentuk oleh Panwaslu secara hirarkis. Model kelembagaan Panwaslu semacam ini ternyata menjadi salah satu kunci persoalan buruknya hubungan kelembagaan dan fungsional KPU dan Panwaslu.

Di tingkat kelembagaan, ketegangan terjadi menyangkut luas lingkup kewenangan Panwaslu. KPU mengangap tugas Panwaslu tidak mencakup mengawasi KPU sebagai organisasi, tetapi terbatas melakukan pengawasan fungsional terhadap semua proses dan pelaksanaan Pemilu. Dalam tugas tersebut, fokus pengawasanya lebih pada peserta pemilu dan masyarakat pemilih untuk menjamin tegaknya dan melakukan langkah-langkah hukum terhadap siapa saja yang melakukan kejahatan terhadap prinsip free and fair election.

Tetapi bagi Panwaslu adalah sulit dan hampir tidak mungkin memisahkan antara pengawasan fungsional dan kelembagaan karena dalam beberapa kesempatan problem fungsional, atau masalah-masalah di lapangan dipicu oleh keputusan KPU atau karena kegagalan KPU memenuhi target waktu, sehingga tidak mungkin bagi Panwaslu untuk 
tidak menyatakan bahwa sebab dari ketidakberesan suatu tahapan atau proses karena keputusan atau tindakan KPU sendiri. Salah satu contoh misalnya mekanisme pendaftaran pemilih dan keterlambatan logistik Pemilu yang berimplikasi pada tahapan pemilu lainnya.

Di tingkat propinsi, kabupaten/kota dan kecamatan ketegangan kedua lembaga jauh lebih tinggi. Di beberapa propinsi bahkan terjadi saling serang secara terbuka di media massa. Sebab utamanya karena Panwaslu di level tersebut bukan bentukan KPU sebagaimana di pusat, tetapi oleh Panwaslu secara hirarkies sehingga ada semacam "kesombongan" kelembagaan dari terutama Panwaslu terhadap KPU dalam bentuk secara terang-terangan memfokuskan pengawasan kepada lembaga KPU. Kalaupun terdapat hubungan kelembagaan yang kondusif dan produktif di beberapa propinsi, termasuk di Yogyakarta lebih karena kedekatan personal diantara anggota kedua lembaga.

Ketidakharmonisan hubungan kelembagaan dan fungsional juga terjadi akibat pengaturan penegakan hukum terhadap pelanggaran Pemilu yang menjadi kewenangan Panwaslu dan KPU tidak bisa dijalankan secara mekanistik akibat keterbatasan waktu, dan ketidakjelasan aturan mainnya sendiri. Rekomendasi Panwaslu agar KPU melakukan tindakan administratif kepada peserta Pemilu yang melanggar aturan tidak bisa dilakukan karena batas waktu yang ditentukan oleh aturan telah terlampaui. Misalnya rekomendasi Panwaslu agar sebuah Parpol atau calon dibatalkan haknya untuk kampanye di putaran terakhir karena melanggar aturan kampanye tidak bisa dilaksanakan karena Parpol atau calon bersangkutan memang sudah tidak memiliki hak kampanye lagi (sudah selesai).

Hal lain misalnya menyangkut putusan. Dalam undang-undang disebutkan bahwa sifat dari penyelesaian sengketa dari pengawas pemilu adalah Final dan Mengikat sebagaimana disebut dalam Pasal 129 ayat (1) Undang-Undang Nomor 12 Tahun 2003 yang berarti bisa langsung dilaksanakan dan mengikat para pihak serta membawa akibat bagi para pihak. Dalam kenyataan, ketentuan ini sukar dilaksanakan, terutama apabila penyelenggara pemilu (KPU pusat dan daerah) tidak bersedia melaksanakan putusan penyelesaian sengketa ini. Pelaksanaan tersebut makin sukar lagi apabila undang-undang pemilu sama sekali tidak menyebut apa implikasi atau akibat bagi penyelenggara yang tidak mau mematuhi putusan pengawas pemilu. Sebagai contoh dari kasus seperti ini terjadi antara lain terhadap putusan Panwas Pemilu Kota Tangerang 
dan Panwas Pemilu Kota Semarang yang menyelesaikan sengketa terkait pendaftaran calon anggota legislatif. ${ }^{43}$

Dengan demikian menjadi jelas bahwa tidak adanya hubungan kelembagaan dan fungsional KPU dengan Panwaslu yang sinergis tidak saja disebabkan karena aspek struktural (posisi kelembagaan Panwaslu), tetapi juga legal dan fungsional. Lalu bagaimana sebaiknya hubungan kelembagaan dan fungsional kedua lembaga itu ke depan?

\section{Format Hubungan ke Depan}

Mengawasi pada hakekatnya merupakan tindakan untuk secara terus menerus mengingatkan pelaksana agar tetap memperhatikan atau mempedomani aturan, kaidah, norma serta hukum yang berlaku agar proses pemilu berjalan secara fair, adil, dan transparan sehingga hasilnya diterima dan dipercaya masyarakat. Dalam konteks institusi pelaksana Pemilu yang independen, lembaga pengawas sesungguhnya built-in di dalam kelembagaan independen itu sendiri. ${ }^{44}$ Pemberian kewenangan selaku penyelenggara dan pengawas oleh UU No. 12 Tahun 2003, menurut Jimly mengandung makna bahwa KPU cukup menjalankan fungsi policy maker dan regulator. Sedangkan untuk pelaksanaan Pemilu dan Pengawas Pemilu, KPU membentuk Panitia Pelaksana Pemilu dan Panitia Pengawas Pemilu, yang seluruhnya bersifat ad hoc, dibentuk dan bertanggungjawab kepada KPU, serta anggota-anggota dan pimpinannya diangkat dan diberhentikan oleh KPU. ${ }^{45}$

Dengan demikian, persoalan pengawasan Pemilu tidak saja menyangkut di mana fungsi pengawasan pemilu itu akan diletakkan, tetapi juga yang lebih penting, bagaimana menegakkan obyektivitas pelaksanaan pengawasan oleh KPU. Untuk menjawab persoalan obyektivitas pengawasan, pelembagaan dengan membentuk badan di dalam KPU adalah kemungkinan yang bisa dilakukan. Apalagi pemilu ini sudah menjadi "industri demokrasi", sehingga diperlukan lembaga yang bersifat permanen di dalam internal KPU itu sendiri.

Di dalam KPU dibayangkan ada badan khusus yang melaksanakan fungsi pengawasan internal atau semacam inspektorat. Di dalamnya bukan

\footnotetext{
${ }^{43}$ Laporan Tertulis Panwaslu, hlm. 129

${ }^{44}$ Suparman Marzuki, "Sinergitas Kerja KPU dan Panwaslu”, Makalah pada lokakarya nasional yang dilaksanakan Panwaslu di Bali, 3 Februrari 2004

${ }^{45}$ Jimly, Op.Cit., hlm. 237
} 
hanya terdiri atas orang-orang KPU dan masyarakat, tetapi unsur penegak hukumnya ada di situ. Dalam badan internal itu perlu dimasukkan pula orang-orang yang punya kemampuan di bidang penyelesaian perselisihan, sehingga ada alternative dispute resolution-nya (ADR).

Sekadar contoh, Komisi Pemilu Thailand memiliki Direktorat Penyelidikan dan Direktorat Adjudikasi, karena aturan pemilunya memungkinkan diadakannya penyelidikan jika terjadi pelanggaran pemilu. Anggotanya diambil dari pihak kepolisian, kejaksaan, pengacara, dan lembaga swadaya masyarakat (LSM). Jika disetujui, KPU juga merancang penataan struktur organisasi KPU agar lebih mendukung "bisnis inti” KPU.

Penyelesaian pelanggaran pidana ringan sebaiknya tidak perlu melalui penuntut umum, tetapi langsung ke pengadilan ad hoc agar prosesnya cepat. Untuk penyelesaian pelanggaran pidana berat melalui penuntut umum dan diproses melalui hukum acara pidana biasa. Khusus untuk penyelesaian pelanggaran yang berpengaruh signifikan terhadap hasil penghitungan suara, diingatkan harus ada pembatasan waktu. Sementara hakim ad hoc dalam pengadilan ad hoc pemilu disarankan bisa berasal dari dalam KPU, akademisi, atau hakim yang memiliki keahlian khusus di bidang pemilu. Pengadilan ad hoc semacam peradilan niaga dan peradilan hak asasi manusia (HAM) adalah model yang ditawarkan untuk menyelesaikan berbagai pelanggaran pidana dalam pelaksanaan pemilu.

Ada pemikiran agar KPU menjadi peradilan tingkat pertama untuk kasuskasus pelanggaran administratif di mana para pihak tidak puas dan melanjutkan ke pengadilan. Untuk itu, Pengadilan Negeri menjadi pengadilan tingkat bandingnya. Namun, untuk kasus pidana, KPU tidak memiliki kewenangan untuk itu dan meneruskannya ke pengadilan. Berkaitan dengan itu, kerja sama KPU dengan MA dan Departemen Kehakiman dan HAM diperlukan agar Pengadilan Negeri betul-betul siap membantu KPU.

\section{Penutup}

Lembaga pengawas Pemilu ke depan seyogyanya berada, dibentuk dan menjadi bagian dari kelembagaan KPU itu sendiri. Bukan lembaga terpisah. Point pertama yang menguatkan pandangan ini adalah bahwa independensi struktural, fungsional dan personal KPU merupakan garansi konstitusional yang harus dipercaya. Tiga pilar kekuatan KPU (independensi struktural, independensi fungsional, dan independensi personal) harus terus dijaga dan dipertahankan. Bahwa dalam dua pelaksanaan Pemilu (1999 dan 2004) 
KPU belum optimal, tidak lantas mengambil kesimpulan bahwa model kelembagaan dan fungsional KPU harus dirombak atau dikontrol (diawasi) secara ketat dengan dan melalui kelembagaan di luar KPU.

Karena kinerja KPU sangat ditentukan juga oleh mutu sumber daya dan kerja sekretariat, maka unsur sekretariat KPU yang oleh UU No. 12 tahun 2003 ditempatkan sebagai unsur pendukung patut ditata ulang, baik personilnya maupun kelembagaannya. Selama ini hubungan KPU dan Sekretariat jauh dari memuaskan, baik karena perbedaan kultur dan gaya personil. Sekretariat dari unsur PNS dengan KPU yang notabene dari kalangan kampus, LSM, Pers dan kelompok masyarakat, tetapi juga karena tata kerja organisasi keduanya yang diatur dalam UU No.12 Tahun 2003 tidak jelas (kabur). Akibatnya seringkali terjadi perselisihan, bahkan di beberapa propinsi dan kabupaten/kota ditandai pemecatan sekretaris KPU.

Dalam tubuh KPU seolah-olah ada dua lembaga; KPU dan Sekretariat atau dua nakhoda dalam satu kapal. Pihak sekretariat merasa tidak punya ketergantungan struktural kepada KPU karena mereka diangkat dan diberhentikan oleh Presiden/Gubernur/Bupati/Walikota. Mentalitas ketaatan komando yang dibangun dan dikembangkan rezim Orde Baru telah melekat dalam ditubuh para $\mathrm{PNS}^{46}$ itu sehingga yang ada adalah monoloyalitas untuk kepentingan birokrasi itu sendiri. ${ }^{47}$

Budaya birokrasi Orde Baru berupa patrimonialisme dan patron-client menguasai hubungan antara birokrat dengan komponen lain dalam struktur birokrasi, meskipun birokrasi itu tidak dalam hubungan kepentingan dengan KPU. Budaya mendahulukan keselamatan jabatan dan dominasi nilai-nilai materialisme serta hedonisme telah mendorong apa yang oleh Soedjatmoko disebut "disjuntion between power and morality". ${ }^{4}$ Tidak aneh bila rapatrapat, bepergian, atau pengadaan lebih disukai dibanding program

${ }^{46}$ PNS (Pegawai Negeri Sipil) di Indonesia dipahami sebagai aparatur pemerintah, yang karena itu taat dan menjadi alat pemerintah; bukan aparatur negara sebagaimana di negara-negara demokrasi maju seperti Jerman. Sebagai aparatur negara (states aparatus) PNS di (Jerman) tunduk dan mengabdi kepada kepentingan masyarakat. Penjelasan menarik tentang ini dapat dibaca dalam Pipit R. Kartawidjaja, "Pemerintah Bukanlah Negara Studi Komparasi Administrasi Pemerintah RI dengan Negara Jerman, Henk Publishing, 2006, hlm.2-12.

${ }^{47}$ Baca Mohtar Mas'Oed, Restrukturisasi Masyarakat oleh Pemerintah Orde Baru, Prisma 7; hlm. 15-20 tahun 1987.

${ }^{48}$ Kenneth W. Thomson, "Introduction" dalam Selo Soemardjan dan Kenneth Thomson (eds), Culture, Development and Democracy: A Tribute to Soedjatmoko. Tokyo: United Nation University Press, 1994, hlm. 2 
sosialisasi atau pendidikan pemilih yang melibatkan kelompok-kelompok masyarakat sipil (LSM, Perguruan Tinggi) dalam bentuk diskusi, ceramah dan semacamnya. ${ }^{49}$ Karena itu (sekali lagi) sangat sukar mengajak mereka berdiskusi, mengambil keputusan, dan melaksanakan keputusan tentang program yang berorientasi pada kepentingan masyarakat sipil. Berbagai alasan mereka lakukan; tidak ada dana, tidak ada dalam rencana program, dan seterusnya.

Dari sudut lain, mental birokrasi yang khas birokrat Indonesia terutama dalam soal penanganan keuangan yang bisa diidentikkan dengan kecenderungan state-stewardship, ${ }^{50}$ pada pemerintah secara umum, yaitu sifat "mengendalikan" secara penuh keuangan dengan mengisolasi KPU.

Ketidakjelasan hubungan struktural dan fungsional inilah sesungguhnya masalah paling serius yang harus dibenahi ke depan. Kalau tidak maka persoalan serupa akan terulang. Jika saja unsur sekretariat diisi oleh kalangan non-PNS, tetapi kalangan profesional, maka bisa diharapkan kinerja KPU ke depan lebih berkualitas. Tetapi lebih dari itu, membangun sebuah lembaga demokrasi yang kuat dan dipercaya membutuhkan waktu dan kesabaran yang relatif lama. Negara-negara demokrasi maju di Eropa dan Amerika membutuhkan 100-150 tahun untuk sampai pada model kelembagaan dan fungsional pelaksana Pemilu yang kuat, solid dan dipercaya. Mereka juga telah melewati masa-masa sulit sebagaimana yang kita alami, tetapi mereka memiliki kekuatan kesabaran sangat tinggi membangun kepercayaan-kepercayaan; dimulai dari kepercayaan antar individu, individu dengan masyarakat sampai kemudian menjadi kepercayaan umum. ${ }^{51}$ Karena itu, bangsa ini harus mampu membangun kepercayaan (trust,) karena trust kata Fukuyama ${ }^{52}$ adalah harapan-harapan terhadap keteraturan, kejujuran dan perilaku kooperatif yang muncul dari dalam sebuah komunitas yang didasarkan pada norma-norma.

Menguatnya pengetahuan dan kesadaran individu dan masyarakat terhadap instrumen demokrasi, yang notabene juga instrumen legal, merupakan jalan bagi tumbuh kembangnya order (ketertiban) dan

${ }^{49}$ Lelucon dikalangan PNS sendiri menyatakan bahwa program-program yang diajukan KPU sulit mewujudkan "kesejahteraan".

${ }^{50}$ Lihat Ibid "Politik, Birokrasi dan Pembangunan, Yogyakarta, Pustaka Pelajar, 1994, hlm. 60

${ }^{51}$ Pernyataan ini dilontarkan oleh Christian Reinheim, pemantau Eropa saat berkunjung ke KPU DIY pada Pemilu 2004 yang lalu.

${ }^{52}$ Francis Fukuyama, TRUST Kebijakan Sosial dan Penciptaan Kemakmuran (terjemahn), Qalam, 1995, hlm. xiii 
kepercayaan (trust). Kedua aspek tersebut merupakan modal sosial (social capital) bagi masyarakat, bangsa dan negara ke depan karena modal sosial adalah akumulasi dari interaksi manusia, dalam bentuk rasa percaya, saling pengertian dan kesamaan nilai dan perilaku yang mengikat anggota dalam sebuah jaringan kerja dan komunitas yang memungkinkan adanya kerjasama. Meminjam pandangan Francis Fukuyama modal sosial adalah "the ability of people to work together for common purposes in groups and organizations". ${ }^{53}$ Dalam skala lebih luas, pandangan Fukuyama bisa diartikan sebagai kemampuan manusia Indonesia untuk hidup bersama sebagai satu bangsa dan satu negara membangun tujuan bersama, yaitu negara hukum demokratis.

\section{Daftar Pustaka}

AS. Hikam, Politik Kewarganegaraan Landasan Redemokratisasi di Indonesia, Erlangga, 1999..

Andre Uta Ujan, Keadilan dan Demokrasi Telaah Filsafat Politik John Rawls, Kanisius, 2001

AE. Priyono, dkk (ed), "Gerakan Demokrasi di Indonesia Pasca Soeharto", Demos, 2003.

Adnan Buyung Nasution, Pergulatan Tanpa Henti Pahit Getir Merintis demokrasi, Aksara Karuna, 2004,

Afan Gaffar, Politik Indonesia Transisi Menuju Demokrasi, Pustaka Pelajar, 2005.

Diamond, Larry; Developing Democracy: Toward Consolidation, Baltimore: The Johns Hopkins University Press, 1999

Fukuyama, Francis; TRUST Kebijakan Sosial dan Penciptaan Kemakmuran (terjemahn), Qalam, 1995.

Gotteher,Dean; "Ombudsman Legislative Resource Document, International Ombudsman Institute, 1998.

Gregorius Sahdan, Jalan Transisi demokrasi Pasca Soeharto, Pondok Edukasi, 2004

HCB. Dharmawan A. Soni BL De Rosari (ed); Siapa Mau Jadi Presiden Debat Publik Seputar Program dan Partai Politik pada Pemilu 2004, Kompas, 2004.

Huntington, P Samuel; The Third Wave: Democratization in the Late Twentieth Century, Norman: Oklahoma University Press, 1991.

\footnotetext{
${ }^{53}$ Ibid;
} 
Ian Shapiro \& Casioano Hacker-Cordon (ed), "Democracy"s Value", Cambridge University Press, 1999

Jimly Asshiddiqie, Perkembangan dan Konslidasi Lembaga Negara Pasca Reformasi, Sekretariat Jenderal dan Kepaniteraan Mahkamah Konstitusi RI, 2006.

Koirudin, Profil Pemlu 2004 Evaluasi Pelaksanaan, Hasil dan Perubahan Peta Politik Nasional Pasca Pemilu Legislatif 2004, Pustaka Pelajar, 2004.

Moh. Mahfud MD. "Membangun Politik Hukum Menegakkan Konstitusi, LP3ES, 2006.

R. Kartawidjaja, "Pemerintah Bukanlah Negara: Studi Komparasi Administrasi Pemerintah RI dengan Negara Jerman, Henk Publishing, 2006.

Schumpeter, Joseph; Capitalism, Socialism, and Democracy, New York: Harper, 1947

Sorensen, Georg; Demokrasi dan Demokraratisasi Proses dan prospek dalam Sebuah Dunia yang Sedang Berubah, (terj), Pustaka Pelajar \& CCSS, 2003.

Sudarsono, Mahkamah Konstitusi Sebagai Pengawal demokrasi, Penyelesaian Sengketa Hasil Pemilu 2004 Oleh Mahkamah Konstitusi, 2005.

Th. Sumartana, dkk (ed), "Mendidik Manusia Merdeka" 65 Tahun Y.B. Mangunwijaya, Interfidei, 1995.

W. Thomson, Kenneth "Introduction" dalam Selo Soemardjan dan Kenneth Thomson (eds), Culture, Development and Democracy: A Tribute to Soedjatmoko. Tokyo: United Nation University Press, 1994.

Zakaria, Fareed; The Future of Freedom: Illiberal Democracy at Home and Abroad, New York: W.W. Norton, 2003

Jurnal Ilmu Pemerintahan, edisi 19 Tahun 2003

Prisma no. 7 tahun 1987.

Analisis CSIS. Tahun XXXII/2003. No. 2

Bivitri Susanti, Menata Ulang Kedudukan Wakil Rakyat, Makalah, IRE, Menuju Pemilihan Umum Transformatif, IRE, Annual Report 2003/2004, Seri Makalah IFES, Bagian 4, Mei 2003.

Suparman Marzuki, "Sinergitas Kerja KPU dan Panwaslu”, Makalah pada lokakarya nasional yang dilaksanakan Panwaslu di Bali, 3 Februrari 2004

Laporan Tertulis Panwaslu tahun 2004

http://stardict.sf.net http://www.usombudsman.org. http://www. KPU.or.id. 